\title{
Idiopathic Reactive Hypoglycemia: Mechanisms of Onset and Remission with High Protein Low Carbohydrate Diet
}

\author{
Keshavan Prakash', Mary Kabadi', Udaya M. Kabadi² ${ }^{*}$ \\ ${ }^{1}$ Endocrine Section, V A Medical Center, Des Moines, IA, USA \\ ${ }^{2}$ University of lowa, lowa, IA, USA \\ Email: ukabadi@gmail.com
}

Received 19 July 2015; accepted 20 September 2015; published 23 September 2015

Copyright (C 2015 by authors and Scientific Research Publishing Inc.

This work is licensed under the Creative Commons Attribution International License (CC BY). http://creativecommons.org/licenses/by/4.0/

(c) (i) Open Access

\section{Abstract}

Objective: Idiopathic reactive hypoglycemia is defined as early postprandial hypoglycemia occurring on ingestion of high carbohydrate containing meal. Remission ensues with high protein low carbohydrate diet. This study assessed roles of insulin and glucagon in its onset and remission. Methods: Plasma glucose, insulin and glucagon were determined after an overnight fast and repeatedly until 180 minutes on ingestion of 3 meals; $100 \mathrm{~g}$ glucose; $100 \mathrm{~g}$ pure protein liquid and mixture of $50 \mathrm{~g}$ each at 14 days' interval. Five adults with IRH and 6 age matched healthy volunteers participated. Results: In IRH, glucose ingestion induced prompt rise in glucose $(5.1 \pm 0.8$ to10.5 $\pm 1.2 \mathrm{mM} / \mathrm{L})$ followed later by hypoglycemia $(2.6 \pm 0.4 \mathrm{mM} / \mathrm{L})$. Insulin rose from $7 \pm 2$ to $90 \pm$ $18 \mathrm{mU} / \mathrm{L}$. Glucagon rose initially $(10 \% \pm 2 \%)$ from elevated basal concentration (373 $\pm 57 \mathrm{mU} / \mathrm{L})$ followed by later decline $(-43 \% \pm 12 \%)$. On protein ingestion, glucose declined followed by a restoration to basal level while both insulin and glucagon rose $(28 \pm 6 \mathrm{mU} / \mathrm{L} ; 148 \% \pm 38 \%, p<0.01)$. However, insulin response was lower and glucagon rise was greater when compared to responses on glucose ingestion $(\mathrm{p}<0.01)$. With mixed meal, glucose $(8.2 \pm 0.6 \mathrm{mM} / \mathrm{L})$, insulin $(65 \pm 12 \mathrm{mU} / \mathrm{L})$ and glucagon $(48 \% \pm 7 \%)$ responses were lesser than rises following glucose ingestion $(p<0.05)$ and hypoglycemia did not occur. Conclusion: In IRH, initial hyperglycemia on glucose ingestion may be exacerbated by paradoxical glucagon rise and hypoglycemia may be induced by increased insulin and declining glucagon responses. Resolution of hypoglycemia with high protein low carbohydrate diet may be attributed to blunting of insulin response and concurrent glucagon rise.

\section{Keywords}

Idiopathic Reactive Hypoglycemia, High Protein, Low Carbohydrate Diet

\footnotetext{
"Corresponding author.
}

How to cite this paper: Prakash, K., Kabadi, M. and Kabadi, U.M. (2015) Idiopathic Reactive Hypoglycemia: Mechanisms of Onset and Remission with High Protein Low Carbohydrate Diet. Open Journal of Endocrine and Metabolic Diseases, 5, 117-123. http://dx.doi.org/10.4236/ojemd.2015.59015 


\section{Introduction}

Idiopathic reactive hypoglycemia (IRH) is also described as early postprandial hypoglycemia often documented to occur within 2 hours after a meal containing a high carbohydrate content or following ingestion of a simple or a refined carbohydrate, e.g. sucrose or glucose [1]-[6]. High protein low carbohydrate diet frequently resolves postprandial hypoglycemia [1]-[6]. However, the pathophysiologic mechanism in induction of remission by intake of high protein, low CHO diet is not examined. Therefore, this study was conducted to assess the role of insulin and glucagon regulation in subjects documented to manifest this syndrome following oral administration of diets containing variable quantities of protein and carbohydrate.

\section{Subjects and Methods}

Five ambulatory subjects, 3 men and 2 women with ages 26 - 45 years with a diagnosis of Idiopathic reactive hypoglycemia as previously established by occurrence of hypoglycemia (Plasma glucose $<50 \mathrm{mg} / \mathrm{dl}$ with symptoms) during $75 \mathrm{~g}$ oral glucose tolerance test after overnight fast. Subjects were not on any medication at the time of the study. 6 age matched (24 - 42 years) healthy volunteers ( 3 men and 3 women) also participated. Informed consent was obtained from all subjects prior to participation. The study protocol was approved by Institutional Research and Development committee as well as Human Study Subcommittee.

Plasma insulin and glucagon concentrations were determined after an overnight fast and at repeated intervals until $180 \mathrm{~min}$ after ingestion of [1] $100 \mathrm{~g}$ of glucose [2] $100 \mathrm{~g}$ of pure protein liquid and [3] a mixture of $50 \mathrm{~g}$ glucose and 50 g pure protein liquid. Dietary studies were conducted at interval of 7 - 15 days in a randomized sequence as described in our previous studies [7] [8]. Plasma glucose and insulin responses following meals were expressed as the absolute changes from fasting levels whereas plasma glucagon changes following meals were expressed as \% change from basal concentrations. All plasma concentrations were determined by commercial kits with methods established in our laboratory. Intra assay and inter assay coefficients of variation for all determinations were $8-10 \%$ in our laboratory. Comparisons were conducted between fasting concentrations and between plasma responses following ingestion of individual dietary meal as well as for responses between meals. Statistical analyses were performed by students' " $\mathrm{t}$ ” test and analysis of variance.

\section{Results}

Fasting plasma glucose and insulin concentrations were not significantly different prior to ingestion of each individual meal and were within the normal range (Table 1). However, fasting plasma glucagon was markedly higher during all 3 studies in comparison to normal subjects (Table 1). After ingestion of 100 g. glucose meal, a significantly greater initial (30 - $60 \mathrm{~min}$ ) rise in plasma glucose was noted in subjects with IRH when compared to healthy volunteers. However, this rise in plasma glucose was followed by a later hypoglycemia in subjects with IRH but not in healthy volunteers. Plasma insulin rose promptly following the initial rise in glucose in all subjects. However, the rise in insulin was markedly higher in subjects with IRH in comparison to healthy volunteers. Glucagon level showed a paradoxical initial increase in 15 - 30 min followed by a later decline at 60 minutes in subjects with IRH whereas a decline alone was noted in healthy volunteers (Figure 1, Table 2 and Table 3).

After 100 g protein meal (Figure 2, Table 2 and Table 3), plasma glucose showed an initial decline followed by a rise to basal level and the fall was significantly greater in subjects with IRH in comparison to normal subjects. However, hypoglycemia noted after pure glucose ingestion did not occur. Both plasma insulin and glucagon rose promptly in all subjects with no significant difference amongst groups of subjects. However, insulin response was significantly lower and glucagon response was significantly greater in comparison to the responses to ingestion of $100 \mathrm{~g}$ glucose meal.

Finally, in subjects with IRH, on administration of a mixed meal, 50 g protein and 50 g glucose, a modest rise in plasma glucose ensued without a subsequent decline to hypoglycemic concentration. Similarly, both plasma insulin and glucagon responses were also intermediate when compared with responses following other meals without significant falls below the basal concentrations (Figure 3, Table 2 and Table 3).

\section{Discussion}

Postprandial hypoglycemia is well documented to occur in several disorders [9]-[12]. It is classified into early 

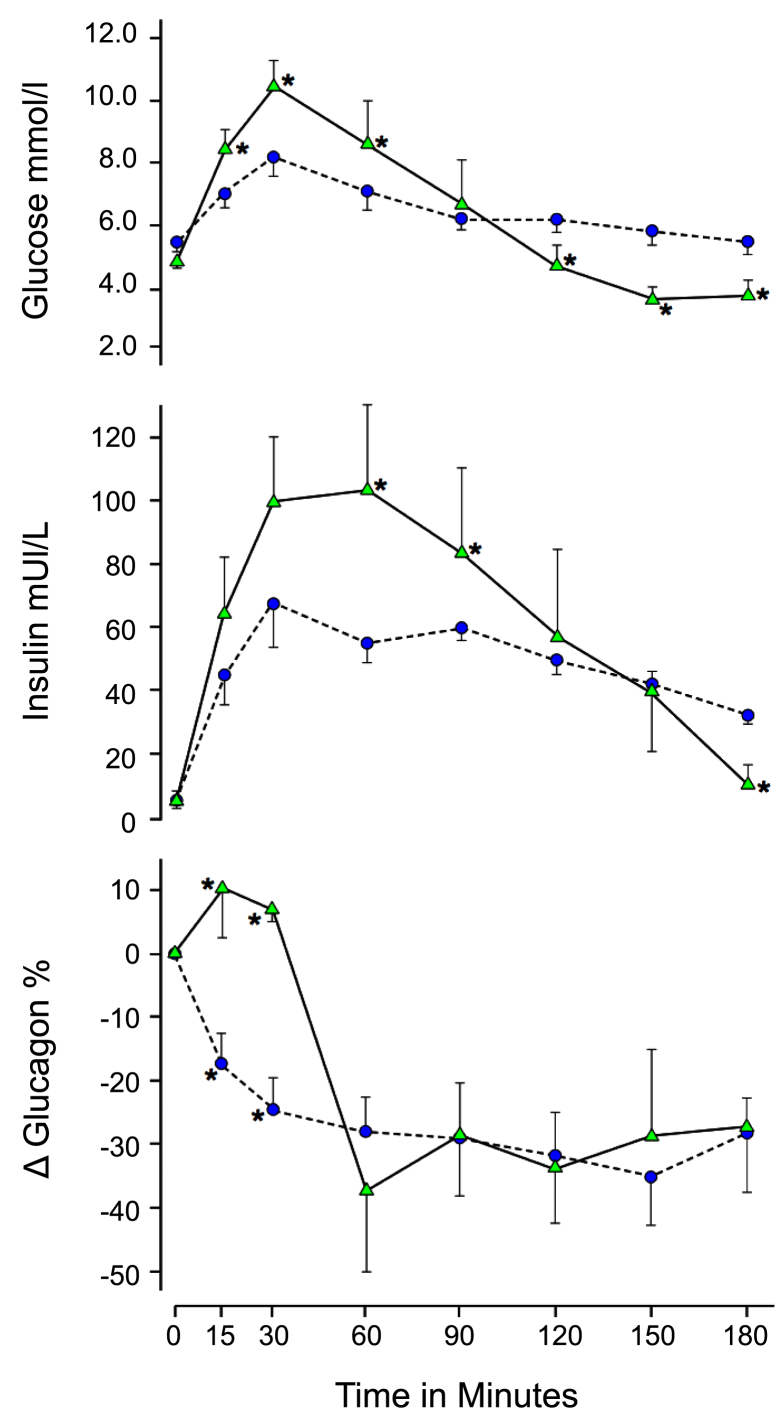

Figure 1. Glucose, insulin, and $\Delta$ Glucagons response to oral ingestion of $100 \mathrm{~g}$ glucose (OGTT) in 5 subjects with IRH $(\Delta)$ and 6 normal subjects $(\bullet) .{ }^{*} \mathrm{P}<0.01$ vs. normal.

Table 1. Fasting plasma glucose, insulin, and glucagon levels in five subjects with IRH and six normal subjects.

\begin{tabular}{cccccc}
\hline Group & Age $(\mathrm{yr})$ & Body Weight & $\begin{array}{c}\text { Fasting Plasma } \\
\text { Glucose }\end{array}$ & $\begin{array}{c}\text { Fasting Plasma Insulin } \\
(\mathrm{mU} / \mathrm{L})^{*}\end{array}$ & $\begin{array}{c}\text { Fasting Plasma } \\
\text { Glucagon }(\mathrm{ng} / \mathrm{L})^{*}\end{array}$ \\
\cline { 3 - 6 } & & $(\mathrm{kg})$ & $4.9 \pm 0.2$ & $7 \pm 2$ & $347 \pm 83^{\dagger}$ \\
IRH & $37 \pm 6$ & $59 \pm 8$ & $5.2 \pm 0.1$ & $6 \pm 1$ & $135 \pm 20$ \\
\hline
\end{tabular}

"The average of 3 values in individual subjects, 1 during the OGTT and the other during the protein meal study, was used for calculation. ${ }^{\dagger} \mathrm{p}<0.025$, IRH v normal.

and late phase postprandial hypoglycemia. In early phase variety, hypoglycemia ensues within 2 hours after a meal. Early phase hypoglycemia is seen with disorders with rapid gastric emptying, following partial or total gastrectomy as well as gastric bypass surgery [6]. Several studies attribute hypoglycemia to enhanced insulin secretion secondary to abnormally rapid absorption of glucose in patients with the above disorders [1]-[3] [9]-[12]. Alternatively, increased insulin sensitivity, decreased response of glucagon to acute hypoglycemia and glucagon 
Table 2. Fasting [F] concentrations, and peak [P] and nadir [N] responses for plasma glucose [G] following oral administration of glucose $100 \mathrm{~g}$, pure protein liquid $100 \mathrm{~g}$ and mixture of $50 \mathrm{~g}$ each glucose and pure protein liquid in subjects with IRH.

\begin{tabular}{cccc}
\hline & Glucose Liquid & Protein Liquid & Mixture \\
\cline { 2 - 4 } & $100 \mathrm{~g}$ & $100 \mathrm{~g}$ & $50 \mathrm{~g}+50 \mathrm{~g}$ \\
\hline FG (mM/L) & $5.1 \pm 0.8$ & $5.2 \pm 0.7$ & $4.8 \pm 0.6$ \\
PG (mM/L) & $11.7 \pm 1.2^{*}$ & $5.7 \pm 0.7$ & $8.2 \pm 0.6^{\dagger}$ \\
NG (mM/L) & $2.6 \pm 0.4^{\dagger}$ & $4.6 \pm 0.4$ & $4.0 \pm 0.8$ \\
\hline
\end{tabular}

${ }^{*} \mathrm{p}<0.005$ vs FG, ${ }^{\dagger} \mathrm{p}<0.01$ vs FG.
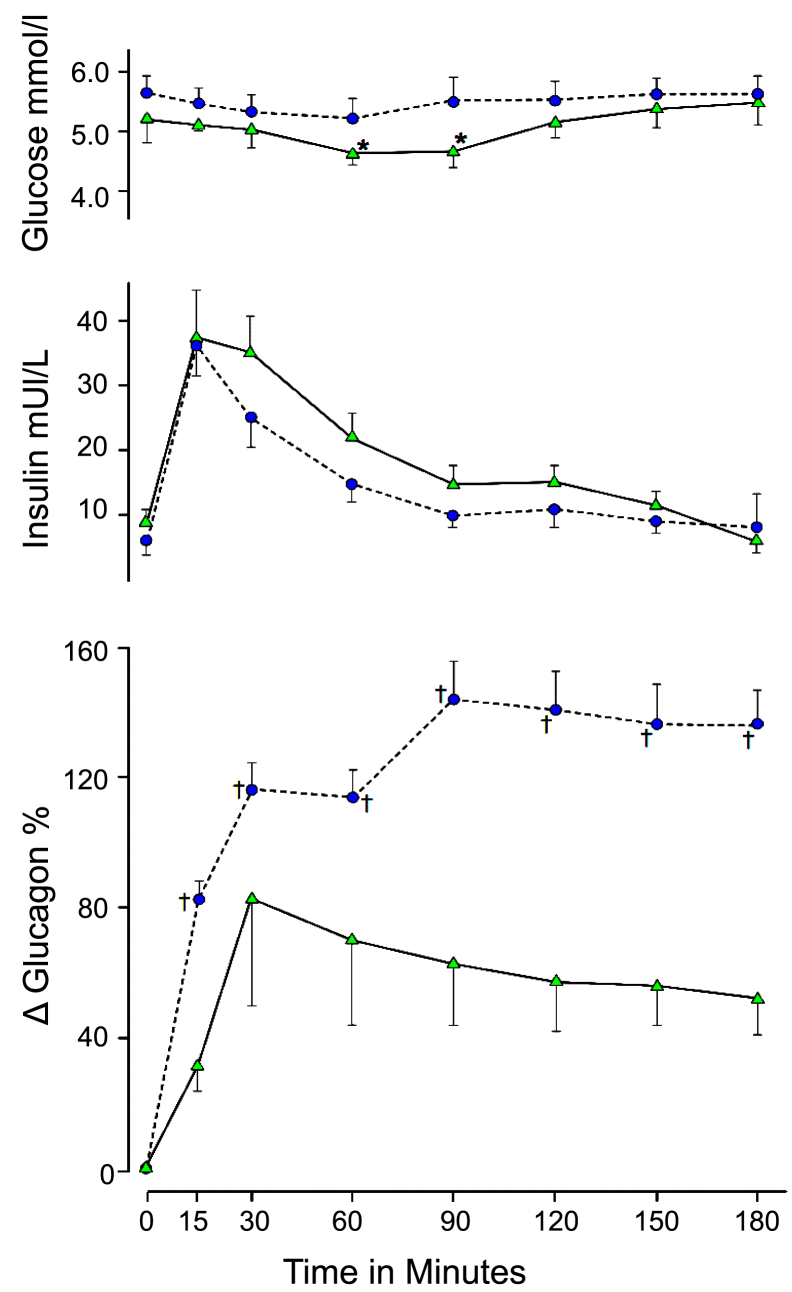

Figure 2. Glucose, insulin, and glucagons response to oral ingestion of a protein meal in 5 subjects with IRH $(\triangle)$ and 6 normal subjects (O ). ${ }^{*} \mathrm{p}<0.05$ vs. normal. ${ }^{+} \mathrm{p}<0.01$ vs. IRH.

receptor down regulation are implicated as possible mechanisms for onset of hypoglycemia [13] [14]. Late phase postprandial hypoglycemia with onset between 3 - 5 hours is documented in subjects with prediabetes secondary to increased $2^{\text {nd }}$ phase insulin secretion [6] [9] [10]. Finally, hypoglycemia occurring after fasting or randomly during the day is induced by islet cell hyperplasia and autoimmune hyperinsulinemia as well as disorders like adrenal or pituitary hypofunction due to lack of counter regulatory hormones as well as end stage liver or renal diseases with reduction in glycogen stores and inhibition of gluconeogenesis [6] [9] [10] [15]-[17]. 

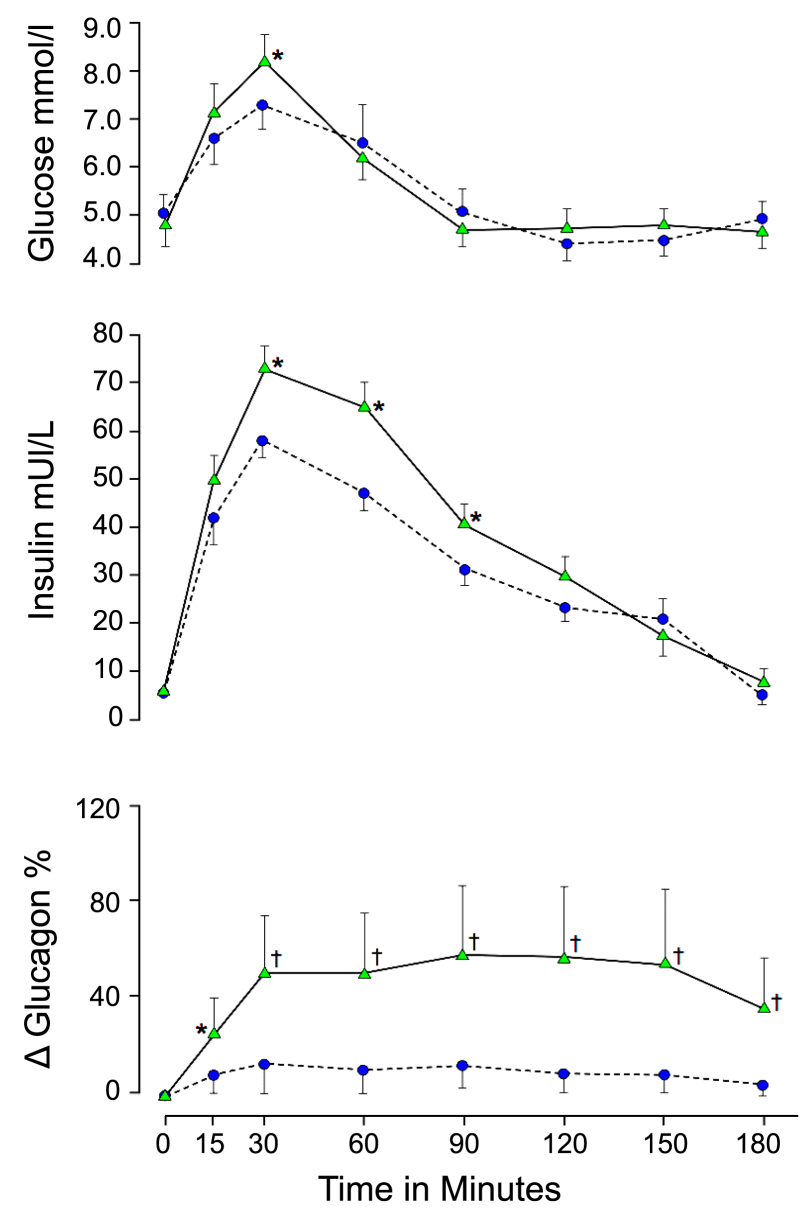

Figure 3. Glucose, insulin, and glucagons response to oral ingestion of a meal of $50 \mathrm{~g}$ glucose and $50 \mathrm{~g}$ protein in $5 \mathrm{sub}-$ jects with $(\bullet)$ and 6 normal subjects $(\triangle)$. ${ }^{*} \mathrm{p}<0.05$ vs. normal. ${ }^{+} \mathrm{p}<0.01$ vs. normal.

Table 3. Fasting [F] concentrations and peak [P] and nadir [N] Insulin [I] and Glucagon [G] responses on oral administration of glucose $100 \mathrm{~g}$, pure protein liquid $100 \mathrm{~g}$ and mixture of $50 \mathrm{~g}$ each, glucose and pure protein liquid in subjects with IRH.

\begin{tabular}{cccc}
\hline & Glucose & Pure Protein & Mixture \\
\cline { 2 - 4 } FI (mU/l) & $100 \mathrm{~g}$ & $100 \mathrm{~g}$ & $50 \mathrm{~g}+50 \mathrm{~g}$ \\
PI (mU/l) & $7 \pm 2$ & $6 \pm 1$ & $7 \pm 3$ \\
NI (mU/l) & $90 \pm 18^{*}$ & $28 \pm 6$ & $65 \pm 12^{\dagger}$ \\
FGL (ng/l) & $8 \pm 2$ & $7 \pm 2$ & $7 \pm 2$ \\
PGL (\% change) & $383 \pm 58$ & $359 \pm 62$ & $376 \pm 57$ \\
NGL $(\% \Delta$ change $)$ & $10 \pm 2^{*}$ & $48 \pm 18$ & $25 \pm 7^{\dagger}$ \\
\hline
\end{tabular}

${ }^{*} \mathrm{p}<0.001$ vs pure protein, ${ }^{\dagger} \mathrm{p}<0.01$ vs pure protein.

Idiopathic reactive hypoglycemia (IRH) is characterized by hypoglycemia occurring within 1 - 2 hour after a meal in otherwise healthy individuals [1]-[6]. In some, it is defined as a one or two hour postprandial glucose level of $\leq 3.0 \mathrm{mM} / \mathrm{L}$ or lower than the fasting glucose level [7] [10]. In contrast to postprandial hypoglycemia 
documented in several other disorders, none of the aforementioned disorder is present in idiopathic reactive hypoglycemia.

Occurrence of hypoglycemia in idiopathic reactive hypoglycemia is attributed to enhanced insulin secretion caused by initial supernormal glucose response to ingestion of glucose [1]-[3] [7] [9] [10] [12]. Basal hyperglucagonemia with altered glucagon regulation is also implicated [7] [8] [14]. In some studies it was also attributed to rapid gastric emptying secondary to lack of rise in Gastric Inhibitory Polypeptide after meal, altered secretion of other gastrointestinal motility factors like Motilin and Bobesin [9]-[12].

Even though medications like metformin, diazoxide, alpha glucosidase inhibitor, glitazones, somatostatin and cholinergic blockers have been studied for treatment of idiopathic reactive hypoglycemia, none of these medications are specifically indicated for this condition [6]-[8] [18]-[21]. Frequent small high protein, low carbohydrate diet remains the mainstay of treatment to prevent hypoglycemia in IRH [1]-[8]. However, the mechanism of this improvement with high protein low carbohydrate diet is not well defined.

This study demonstrates altered glucagon regulation in subjects with IRH. Fasting hyperglucagonemia may indicate depleted glycogen stores as documented in our previous studies [22]-[26]. A lack of appropriate glucagon rise in response to declining plasma glucose may be responsible for prevention of hypoglycemia induced by markedly enhanced insulin stimulation by early marked glucose rise following glucose ingestion. The depleted glycogen stores indicated by fasting hyperglucagonemia may further contribute to the lack of prevention as well. Finally, an enhanced glucagon response and a relative lesser rise in insulin levels may be responsible for remission of hypoglycemia following meals containing protein. Therefore, in conclusion, an initial hyperglycemia after glucose ingestion is likely caused by initial paradoxical glucagon rise, whereas hypoglycemia itself may be caused by increased insulin response and declining glucagon levels. Resolution of hypoglycemia with high protein low carbohydrate diet may be secondary to blunting of insulin response and simultaneous rise in glucagon.

\section{References}

[1] (1971) Medical Staff Conference Reactive Hypoglycemia Mechanisms and Management California Medicine. The Western Journal of Medicine, 114, 64-70.

[2] Betteridge, D.J. (1987) Reactive Hypoglycemia. British Medical Journal (Clinical Research Ed.), 295, 286-287. http://dx.doi.org/10.1136/bmj.295.6593.286

[3] Hofeldt, F.D. (1989) Reactive Hypoglycemia. Endocrinology Metabolism Clinics of North America, 18, $185-201$.

[4] Brun, J.F., Fedou, C. and Mercier, J. (2000) Postprandial Reactive Hypoglycemia. Diabetes \& Metabolism, 26, 337351.

[5] Scheen, A.J. and Lefèbvre, P.J. (2004) Reactive Hypoglycemia, a Mysterious, Insidious but Non Dangerous Critical Phenomenon. Revue Medicale de Liege, 59, 237-242.

[6] Khan, M. and Kabadi, U.M. (2011) Postprandial Hypoglycemia in "Diabetes-Damages and Treatments”. Tech Publisher, Chapter 6, 117-126.

[7] Kabadi, U.M. (1991) Dose-Kinetics of Pancreatic Alpha- and Beta-Cell Responses to a Protein Meal in Normal Subjects. Metabolism, 40, 236-240. http://dx.doi.org/10.1016/0026-0495(91)90103-4

[8] Ahmadpour, S. and Kabadi, U.M. (1997) Pancreatic Alpha-Cell Function in Idiopathic Reactive Hypoglycemia. Metabolism, 46, 639-643. http://dx.doi.org/10.1016/S0026-0495(97)90006-8

[9] Marks, V. and Teale, J.D. (1993) Hypoglycemia in the Adult. Baillière’s Clinical Endocrinology and Metabolism, 7, 705-729. http://dx.doi.org/10.1016/S0950-351X(05)80215-0

[10] Service, F.J. (1995) Hypoglycemic Disorders. The New England Journal of Medicine, 332, 1144-1152. http://dx.doi.org/10.1056/NEJM199504273321707

[11] Middleton, S.J. and Balan, K. (2011) Post-Prandial Reactive Hypoglycaemia and Diarrhea Caused by Idiopathic Accelerated Gastric Emptying: A Case Report. Journal of Medical Case Reports, 5, 177. http://dx.doi.org/10.1186/1752-1947-5-177

[12] Service, G.J., Thompson, G.B., Service, F.J., Andrews, J.C., Collazo-Clavell, M.L. and Lloyd, R.V. (2005) Hyperinsulinemic Hypoglycemia with Nesidioblastosis after Gastric-Bypass Surgery. New England Journal of Medicine, 353, 249-254. http://dx.doi.org/10.1056/NEJMoa043690

[13] Tamburrano, G., Leonetti, F., Sbraccia, P., et al. (1989) Increased Insulin Sensitivity in Patients with Idiopathic Reactive Hypoglycemia. The Journal of Clinical Endocrinology and Metabolism, 69, 885-890. http://dx.doi.org/10.1210/jcem-69-4-885 
[14] Leonetti, F., Morviducci, L., Giaccari, A., et al. (1992) Idiopathic Reactive Hypoglycemia: A Role for Glucagon? Journal of Endocrinological Investigation, 15, 273-278. http://dx.doi.org/10.1007/BF03348727

[15] Cavaco, B., Uchigata, Y., Porto, T., Amparo-Santos, M., Sobrinho, L. and Leite, V. (2001) Hypoglycemia Due to Insulin Autoimmune Syndrome: Report of Two Cases with Characterization of HLA Alleles and Insulin Autoantibodies. European Journal of Endocrinology, 145, 311-316. http://dx.doi.org/10.1530/eje.0.1450311

[16] Kim, C.H., Park, J.H., Park, T.S. and Baek, H.S. (2004) Autoimmune Hypoglycemia in a Type 2 Diabetic Patient with Anti-Insulin and Insulin Receptor Antibodies. Diabetes Care, 27, 288-289. http://dx.doi.org/10.2337/diacare.27.1.288

[17] Hizuka, N., Fukuda, I., Takano, K., Okubo, Y., Asakawa-Yasumoto, K. and Demura, H. (1998) Serum Insulin-Like Growth Factor II in 44 Patients with Non-Islet Cell Tumor Hypoglycemia. Endocrine Journal, 45, S61-S65. http://dx.doi.org/10.1507/endocrj.45.suppl_s61

[18] Richard, J.L., Rodier, M., Monnier, L., Orsetti, A. and Mirouze, J. (1988) Effect of Acarbose on Glucose and Insulin Response to Sucrose Load in Reactive Hypoglycemia. Diabetes \& Metabolism, 14, 114-118. http://dx.doi.org/10.1007/978-3-642-73583-7 46

[19] Arii, K., Ota, K., Suehiro, T., Ikeda, Y., Nishimura, K., Kumon, Y. and Hashimoto, K. (2005) Pioglitazone Prevents Reactive Hypoglycemia in Impaired Glucose Tolerance. Diabetes Research and Clinical Practice, 69, 305-308. http://dx.doi.org/10.1016/j.diabres.2005.01.004

[20] Sørensen, M. and Johansen, O.E. (2010) Idiopathic Reactive Hypoglycemia-Prevalence and Effect of Fibre on Glucose Excursions. Scandinavian Journal of Clinical and Laboratory Investigation, 70, 385-391. http://dx.doi.org/10.3109/00365513.2010.491869

[21] Keller, D. and Santiago, J. (1967) Cholinergic Blockade in Reactive Hypoglycemia. Diabetes, 26, 121-127.

[22] Kabadi, U.M. (1993) Hepatic Regulation of Pancreatic Alpha-Cell Function. Metabolism, 42, 535-543. http://dx.doi.org/10.1016/0026-0495(93)90208-6

[23] Kabadi, U.M. (1992) Is Hepatic Glycogen Content a Regulator of Glucagon Secretion? Metabolism, 41, 113-115http://dx.doi.org/10.1016/0026-0495(92)90135-W

[24] Kabadi, U.M. (1987) The Association of Hepatic Glycogen Depletion with Hyperammonemia in Cirrhosis. Hepatology, 7, 821-824. http://dx.doi.org/10.1002/hep.1840070505

[25] Kabadi, U.M., Eisenstein, A.B. and Konda, J. (1985) Elevated Plasma Ammonia Level in Hepatic Cirrhosis: Role of Glucagon. Gastroenterology, 88, 750-756.

[26] Kabadi, U.M., Eisenstein, A.B., Tucci, J. and Pellicone, J. (1984) Hyperglucagonemia in Hepatic Cirrhosis: Its Relation to Hepatocellular Dysfunction and Normalization on Recovery. American Journal of Gastroenterology, 79, 143149. 